\title{
Stress, coping and presenteeism \\ in nurses assisting critical and potentially critical patients*
}

\author{
ESTRESSE, COPING E PRESENTEÍSMO EM ENFERMEIROS QUE ASSISTEM \\ PACIENTES CRIITICOS E POTENCIALMENTE CRÍTICOS
}

\section{ESTRÉS, COPING Y PRESENTISMO EN ENFERMEROS QUE ASISTEN A PACIENTES CRÍTICOS Y POTENCIALMENTE CRÍTICOS}

\author{
Juliane Umann', Laura de Azevedo Guido², Rodrigo Marques da Silva
}

\begin{abstract}
Objective: to verify the associations between stress, Coping and Presenteeism in nurses operating on direct assistance to critical and potentially critical patients. Method: this is a descriptive, cross-sectional and quantitative study, conducted between March and April 2010 with 129 hospital nurses. The Inventory of stress in nurses, Occupational and Coping Questionnaire Range of Limitations at Work were used. For the analysis, the Kolmogorov-Smirnov test, correlation coefficient of Pearson and Spearman, Chi-square and T-test were applied. Results: it was observed that $66.7 \%$ of the nurses showed low stress, $87.6 \%$ use control strategies for coping stress and $4.84 \%$ had decrease in productivity. Direct and meaningful relationships between stress and lost productivity were found. Conclusion: stress interferes with the daily life of nurses and impacts on productivity. Although the inability to test associations, the control strategy can minimize the stress, which consequently contributes to better productivity of nurses in the care of critical patients and potentially critical.
\end{abstract}

\section{RESUMO}

Objetivo: Verificar as associações entre estresse, Coping e presenteísmo em enfermeiros atuantes na assistência direta a pacientes críticos e potencialmente críticos. Método: Trata-se de um estudo descritivo, transversal e quantitativo, realizado entre março e abril de 2010 com 129 enfermeiros hospitalares. Utilizou-se o Inventário de estresse em enfermeiros, Escala de Coping Ocupacional e Questionário de Limitações no Trabalho. Para a análise, aplicaram-se os testes Kolmogorov-Smirnov, coeficiente de correlação de Pearson e Spearman, QuiQuadrado e o Teste T. Resultados: Observouse que $66,7 \%$ dos enfermeiros apresentaram baixo estresse, $87,6 \%$ utilizam estratégias de controle para o enfrentamento do estresse e $4,84 \%$ tiveram decréscimo na produtividade. Relações diretas e significativas entre estresse e produtividade perdida foram encontradas. Conclusão: $O$ estresse interfere no cotidiano dos enfermeiros e repercute na produtividade. Embora a impossibilidade de testar associações, a estratégia de controle pode minimizar o estresse, o que consequentemente contribui para a melhor produtividade do enfermeiro na assistência a pacientes críticos e potencialmente críticos.

\section{DESCRITORES}

Enfermagem

Cuidados intensivos

Esgotamento profissional

Estresse psicológico

Saúde do trabalhador.

\section{RESUMEN}

Objetivo: Verificar las asociaciones entre el estrés, las estrategias de coping y el presentismo en enfermeros actuantes en la asistencia directa a pacientes críticos y potencialmente críticos. Método: Se trata de un estudio descriptivo, transversal y cuantitativo, realizado entre marzo y abril de 2010 con 129 enfermeros hospitalarios. Se utilizó el Inventario de estrés en enfermeros, la Escala de Afrontamiento Ocupacional y el Cuestionario de Limitaciones Laborales. Para el análisis, se aplicaron las pruebas de Kolmogorov-Smirnov, el coeficiente de correlación de Pearson y Spearman, Chi- Cuadrado y Prueba T. Resultados: Fue observado que el $66,7 \%$ de los enfermeros presentaban estrés bajo, el $87,6 \%$ utilizaban estrategias de control para el coping del estrés y el $4,84 \%$ tuvieron reducción de productividad. Se encontraron relaciones directas y significativas entre el estrés y la productividad perdida. Conclusiones: El estrés interfiere en el cuotidiano de los enfermeros y repercute en su productividad. Aunque sea imposible probar las asociaciones, puede que la estrategia de Control haya minimizado el estrés y consecuentemente contribuido para la mejor productividad del enfermero en la asistencia a pacientes críticos y potencialmente críticos.

\section{DESCRIPTORES \\ Enfermería \\ Cuidados intensivos \\ Agotamiento profesional \\ Estrés psicológico \\ Salud laboral}

\footnotetext{
* Extracted from the dissertation "Stress, coping and presenteeism in hospital nurses", Post-graduation Program in Nursing, Federal University of Santa Maria, 2011. ${ }^{1}$ PhD, Federal University of Rio Grande do Sul, Porto Alegre, RS, Brazil. ${ }^{2}$ PhD Professor, Nursing Department, Federal University in Santa Maria, Santa Maria, RS, Brazil. ${ }^{3}$ Master degree, Post-graduation Program in Nursing, Federal University of Santa Maria, Santa Maria, RS, Brazil
} 


\section{INTRODUCTION}

Productive restructuring experienced in the healthcare sector, as a result of the prevailing capitalist dynamics, implies deep changes, with repercussions on labor organization and workforce on health, especially the nurse. These changes are perceived through the easing of labor relationships, within the framework of quantitative reductions and professionals work scheme based on extra range and/or multi-jobs ${ }^{(1)}$. Among the repercussions brought about by these changes, the demand for greater productivity, the limitation of time and the complexity of the tasks can cause tension, fatigue and exceed the cognitive resources of professionals, constituting situations of stress at work $^{(2)}$.

These issues are based by researchers ${ }^{(3-6)}$ revealing that the organizational aspects, such as work overload, lack of control, insufficient reward and conflicts of values, can influence the performance of hospital labor activities, with damage to physical and mental health of workers and, consequently, interfering with the quality of assistance provided.

Thus, based on the exposed situations, it is possible the occurrence of occupational stress, with impacts on worker's health and organizations, such as: the illness at work (related to high levels of absenteeism); and the reduction of productivity and quality of the services provided $^{(6)}$.

Stress and its relationship with health and quality of life at work has been focused of investigations with nursing professionals, in which the working environment is approached by some authors ${ }^{(2.7-8)}$ as a determining context for the evaluation of specific stressors to occupational demands. In this process, the occupational stress can be defined by the interaction of working conditions with the characteristics of the worker, so labor demand exceeds their skills to face them ${ }^{(9)}$. The confrontation of different demands in the lives of individuals, which includes the occupational, process called Coping, is defined as any individual attempt to adapt to adverse circumstances evaluated as stressful, no matter whether or not success in coping ${ }^{(10)}$.

In the workplace, stress of nurses can arise from the relationship between the remarkable responsibility and limited autonomy to interfere on the productivity of these professionals. From this perspective, there is the presenteeism as the condition in which people come to the workplace, but perform the activities inherent in a nonproductive functions, i.e. not present good performance for mental and physical problems related to work $^{(11)}$.

It is understandable that stress is a complex phenomenon that through the stimulus and the individual's interaction with the internal and external environment, can cause physiological, psychological, emotional and behavioral changes. Furthermore, the labor organization is able to limit the individual's efforts to adapt the individual needs and organizational work.

Thus, the identification of occupational stress and Coping strategies of nurses, as well as the repercussions to their labor activities is an important agent of change. This is because, once possible solutions to minimize its effects are developed, they can make the daily life of these professionals work more productive and less stressful, with the appreciation of the human and professional aspects ${ }^{(10)}$.

From this, the study aimed to verify associations between stress, Coping and presenteeism in hospital nurses who work in assisting critical and potentially critical patients. The option of the the critical and potentially critical patients assistance was due to an increase in demand for these services, caused by the social, economic and cultural transformations in the living conditions of the Brazilian population. These transformations include changes in health problems and needs, combined with the lack of a consolidated service network for this assistance profile and to the distortions and deficits in the provision of such services, which may contribute to the wear of the nurses involved. As a research hypothesis, the use of Coping strategies focused on problem minimizes stress intensity. Thus, the low stress fosters increased productivity of nurses who currently plays in assisting critical and potentially critical patients.

\section{METHOD}

Descriptive, cross-sectional study and quantitative approach, developed in a university hospital in the interior of Rio Grande do Sul, a public and of high complexity institution. It is considered regional health reference in doctor and hospital service and aims to promote assistance, teaching, research and extension services to the community.

For this study, units receiving potentially critical patients were considered (ER, Inpatient Medical Units I and II, Surgical, Ginecologic, Pediatric and Psychiatric); and critical patients (Adult, Pediatric and Neonatal Intensive Care Units, Cardiac Intensive Unit, Blood-Oncology Unit, Obstetrics Center, Surgical Center and Anesthetic Recovery Room, Laboratory of Hemodynamics and Nephrology Service).

Critical patients are those with severe health condition, with commitment from one or more physiological systems, with loss of their self-regulation, need for artificial replacement of functions and continuous assistance. Potentially critical patients are those presenting clinical stability, with potential risk of aggravation of the picture and who need continuous care ${ }^{(12)}$.

The study population was composed of 147 nurses operating in those hospital units, of which 129 were selected
Stress, coping and presenteeism in nurses assisting critical and potentially critical patients Umann J, Guido LA, Silva RM 
according to the criteria: nurses civil servants (permanent staff) and active in direct assistance to patients. Professional apart for license of any kind during the period established for data collection were excluded.

The data were collected in March and April 2010 through a research protocol that consisted of: Form for demographic characterization, Inventory of stress in nurses (ISN), Occupational Coping scale (ECO) and Work limitations questionnaire (WLQ). The questionnaires were delivered into the hands of the participants, with scheduled return for the researcher, according the availability referred to by them.

The form for characterization involved demographic variables (date of birth, gender, education, marital status, number of children, conducting any health treatment) and functional (weekly workload, training, other employment, working time, shift, work absences for illnesses in the last year).

The ISN has been developed and validated for the Brazilian population $^{(9)}$ together with a sample of 461 nurses, civil servants of the Federal District. Factor analysis indicated the presence of a global factor and three first order factors: Interpersonal Relations $(\alpha=0.90)$, Roles of Stressors $(\alpha=0.82)$ and Intrinsic Factors to Work $(\alpha=0.79)$. The results of the value of the factorials loads of items, the values of the Eigenvalues and the internal consistency confirm that the instrument has an appropriate internal structure.

In this way, the ISN provides a general measure of occupational stress of nurses from the identification of stressors and the frequency they are perceived in labor activities.

This inventory is composed of 38 items relating to stressors in the workplace, arranged in a five-point Likert scale ranging from one, noted for the never option, to five, for the frequency always. In this way, the ISN index and their categories will have values ranging between one and five. The items are divided into categories: Interpersonal Relations (17 items), Roles of Stressors (11 items), and Intrinsic Factors to Work (10 items). In the evaluation of the ISN, the average index represents low or high stress for the population, which values below or equal to three are affirmative for the first hypothesis (low stress) and over three for the second (high stress). The averages regarding categories of scale indicate that those that present highest score were considered the stressor prevalent for nurses in the study, i.e., they encompass situations considered more stressful for these professionals.

The ECO was translated and adapted to the Brazilian reality ${ }^{(13)}$ for measuring Coping in the occupational environment. In his adaptation, the ECO has been applied in 397 workers in office environment of Brasília and the factor analysis showed the existence of three qualifying factors: Control, Management and Dodge, whose Alphas
Cronbach's were $0.878,0.813$ and 0.774 respectively. The results provided evidence of criterion validity and reliability to scale.

The ECO is composed of 29 items related to the way people deal with the problems of the workplace, distributed in its three qualifying factors as follows: Control (11 items), Dodge (9 items) and Management of Symptoms ( 9 items). Such items are presented in five-point Likert-type scale ranging from one (1) never do this to five (5) always do it, being that the higher the score of the individual in a particular ECO factor, the greater the frequency he uses this strategy for tackling the occupational stressors.

The WLQ is a translated instrument, culturally adapted and validated to the Brazilian reality ${ }^{(14)}$. In this process, the instrument was applied to 150 patients aged greater than or equal to 18 years old, including staff and graduate students from São Paulo Hospital. Its reliability was evaluated by intraclass correlation and coefficient of Cronbach's alpha. The reliability tester was significant and high (between 0.600 and 0.800$)$ or too high $(0.800$ to 1.000 ) in all damains, with the exception of physical demand ( $r=0.497$, moderate reliability), and internal consistency identified was too high (Cronbach's alpha of 0.800 to 1.000 ). This instrument was developed to evaluate presenteeism from the measure lost productivity associated with the interference of health problems in the performance of activities at work.

The WLQ is composed of 25 items, grouped into four areas of limitation of work that include the multidimensional character of the functions developed in the occupational environment, as: Time Management (5 items), Physical Demand (6 items), Mental-Interpersonal Demand (9 items) and Demand for Production (5 items).

The score of the index represents the percentage of lost productivity in relation to healthy people ${ }^{(14)}$. The domains of the WLQ show a score ranging from zero (without limitation) to 100 (all time with limitation), which indicates the percentage of time in the last two weeks, in which the individual was limited to accomplish their tasks at work.

Socio-demographic variables and the items that include the instruments were statistically analyzed with the software Statistical Package for the Social Sciences (SPSS - version 17.0). The Kolmogorov-Smirnov test was held to verify the adherence of normal distribution data ${ }^{(15)}$. The qualitative variables were described by absolute frequency $(n)$ and relative (\%); and quantitative through descriptive measures (minimum, maximum, average and standard deviation) when satisfy the assumption of normality. In case of normal distribution, these data were described by the median and interquartile range interval.

Tests for correlations between the contents of the WLQ, scores of ISN and ECO, were conducted by the Pearson and 
Spearman coefficient of correlation. The associations between these scales and sorting by unit (critical and potentially critical patients assistance) were verified by the Chisquare test and $\mathrm{T}$ test.

The internal consistency of the scales was assessed by Cronbach's Alpha Coefficient in order to verify the trustworthiness of the extent to which the instruments purport to measure. Values above 0.70 were considered confirmatory for this purpose ${ }^{(15)}$.

Taking into account the guidelines and regulatory norms for Research Involving Human Beings in force during the period of realization of this research (CNS Resolution 196/96), the project was submitted to the Ethics Committee in Research and approved under the Protocol 0312.0.243.000-09. Furthermore, provided an Term of Free and Clarify Consent (TFCC) to participants of the survey, which was signed after the exposure of the goals of the study and clarifications about the research ${ }^{(16)}$.

\section{RESULTS}

The internal consistency of the scales, assessed by Cronbach's Alpha Coefficient, attested the instruments' trust, with values that ranged from 0.78 to 0.95 . Adherence to normality has been taken to the ISN and ECO ranges, except for the Management of Symptoms of this last factor scale that did not answer the normal distribution, as well as the WLQ scales and their domains.
Of the population of 147 nurses operating in critical patients care units and potentially critical hospital institution under study, seven were excluded because they presented in health treatment license (HTL) in the period established for data collection, six because they were moved to administrative posts and three for being retired. Both refused to participate in the study. Thus, 18 nurses were excluded, being the sample of this research comprised of 129 professionals.

As for the demographic characterization, there was a predominance of female nurses (92.2\%) married (65.1\%), with children $(69.5 \%)$ postgraduates $(89.9 \%)$ and who were not in treatment at the time of collection (62.5\%). It was obtained average age of 39.47 years old $(S D=8.99)$, with variation between 25 and 63 years old.

Regarding the functional characterization of the population, it was found that $41.9 \%$ of nurses work night shift, $66.7 \%$ had training, $24 \%$ have another job and $77.5 \%$ perform overtime. The occurrence of absence has been identified in $38 \%$ of nurses and the reasons are diseases diagnosed $(23.3 \%)$ reasons of familiar character $(11.6 \%)$ and both (3.1\%). The average workload was 34.4 hours per week ( $S D=5.09)$, of which, $26.4 \%$ of nurses, the load time corresponded to 40 hours. Working time in the institution and unit was on average of 10.96 and 7.10 years of work, respectively.

Descriptive measures for the ISN, ECO and WCO are presented in Table 1.

Table 1 - Values obtained for the ISN, ECO and WLQ questionnaires - Santa Maria, RS, 2013

\begin{tabular}{|c|c|c|c|}
\hline \multirow{2}{*}{ Instruments/domains } & \multicolumn{3}{|c|}{ SCORES } \\
\hline & Minimum & Maximum & Average (SD) \\
\hline ISN & 1.26 & 4.29 & $2.70(0.63)$ \\
\hline Interpersonal Relationships & 1.00 & 4.82 & $3.59(0.73)$ \\
\hline Roles of Stressors & 1.36 & 4.36 & $2.70(0.62)$ \\
\hline Intrinsic Factors to Work & 1.20 & 4.50 & $2.90(0.72)$ \\
\hline ECO & - & - & - \\
\hline Control Factor & 2.18 & 5.00 & $3.68(0.51)$ \\
\hline Dodge Factor & 1.00 & 4.56 & $2.46(0.65)$ \\
\hline Management of symptoms Factor & 1.00 & 4.89 & $2.50(0.77)$ \\
\hline WLQ & 0.60 & 14.37 & $3.31(2.78)$ \\
\hline Time Management & 0.0 & 70.0 & $9.1(13.39)$ \\
\hline Physical Demand & 8.33 & 62.5 & $26.33(10.77)$ \\
\hline Mental-interpersonal Demand & 0.0 & 58.33 & $11.54(12.75)$ \\
\hline Production Demand & 0.0 & 55.0 & $8.8(12.09)$ \\
\hline
\end{tabular}

Low-intensity stress for this population was identified, since the general average of ISN scale was 2.7 (SD=0.63). There were $66.7 \%$ of nurses with low stress, i.e., values for the average of up to three points on the scale Likert type. Among the situations that represent greater wear, those linked to interpersonal relationships were prevalent, with an average of $3.59(S D=0.73)$, i.e. perceived stressors were more frequently in the daily lives of professionals.

In the analysis of the ISN according to units surveyed, there was average of $2.81(\mathrm{SD}=0.62$ ) for units of assistance to potentially critical patients. Among them, the Pediatric and the ER were those who obtained the highest scores in the evaluation of general occupational stress ( $\bar{X} 3,01$ each; $S D=0,35$ and 0,76 , respectively). In critical patients care units, the average was 2.60 (SD =0.63), except for the service of Nephrology ( $\bar{X} 3,48 ; S D=0,72)$.

It was noted that there is no difference for evaluation of stress among the surveyed units, being that, among nurses with high stress, $62.8 \%$ work in units of assistance to potentially critical patients $(p=0.015)$. 
From the assessment of the occupational Coping by ECO scale, it can be seen that the Control factor had highest average ( $\bar{X} 3,68 ; S D=0,51)$, and is therefore considered to be prevalent for this population (87.6\%).

When analysing Coping averages between units of assistance to critical and potentially critical patients, there was prevalence for the Control factor in both, with averages of $3.62(S D=0.46)$ and $3.74(S D=0.55)$, respectively. With the exception of the service of Nephrology, classified in this study as the unit of assistance to critical patients, whose highest average was for the management of Symptoms ( $\bar{X} 3,44 ; S D=0,59)$, which indicates, therefore, be more strategy used by nurses of this unit.

There were not found associations between units of assistance to critical and potentially critical patients and Coping strategies.

In this study, analyzing the WLQ index score, nurses feature a $3.31 \%$ decrease in productivity. The domain physical demands, which assesses the ability to perform tasks requiring physical strength, endurance, flexibility, coordination and movement, obtained the highest average value ( $\bar{X} 26,33 ; S D=10,77)$, which means that, in the last two weeks, the nurses had limitation greater than $25 \%$ of their time to perform this kind of task in their work.
In the analysis of the results of the WLQ questionnaire, when considering the variability of the measures represented high values of standard deviation and the normal distribution, we opted for submitting through the median and interquartile range, in order to ensure better representation of the data for the population. Thus, for $75 \%$ of nurses, it has an index of productivity lost up to $4.84 \%$.

Considering the median values with regard to inpatient units, the WLQ scores vary from $1.39 \%$ to $6.43 \%$, so that the assistance units potentially critical patients presented general index lost productivity of $2.74 \%$, and units of assistance to critical patients of $2.13 \%$. The Pediatric Unit has obtained greater general index lost productivity in relation to the other units (6.43\%). Hemodynamic laboratory units and medical clinic II presented the smallest general indexes lost productivity, with values of 1.44 and $1.39 \%$, respectively.

To the WLQ scores, trends were not found statistically significant differences in the comparison between units of assistance to critical and potentially critical patients.

Direct and significant correlations were established between the scores of the WLQ scales and ISN (Table 2), which confirms the relationship between stress and lost productivity in nurses who assist critical and potentially critical patients.

Table 2 - Correlation matrix between WLQ x ISN-Santa Maria, RS, 2011

\begin{tabular}{|c|c|c|c|c|c|}
\hline \multirow[b]{2}{*}{ WLQ X ISN } & \multicolumn{5}{|c|}{ Coefficient Correlation of Spearman } \\
\hline & Time Demand & Physical Demand & $\begin{array}{l}\text { Mental-interpersonal } \\
\text { Demand }\end{array}$ & $\begin{array}{l}\text { Production } \\
\text { Demand }\end{array}$ & WLQ Index \\
\hline Interpersonal relationships & $0.335^{*}$ & $0.328^{*}$ & $0.317^{*}$ & $0.307^{*}$ & $0.395^{*}$ \\
\hline Roles of stressors & $0.329 *$ & $0.214 * *$ & $0.389^{*}$ & $0.365^{*}$ & $0.431 *$ \\
\hline Intrinsic at work Factors & $0.235^{*}$ & $0.296^{*}$ & $0.258^{*}$ & $0.292 *$ & $0.353^{*}$ \\
\hline General ISN & $0.323 *$ & $0.332 *$ & $0.323 *$ & $0.339 *$ & $0.416^{*}$ \\
\hline
\end{tabular}

*significance level 0,01

**significance level 0,05

It is worth noting that for the ECO range, the control factor prevalence makes any associations with the scores of other instruments, given the impossibility of being found differences regarding this variable for the group of nurses of this research, on the basis of high representativeness of the population in this factor.

\section{DISCUSSION}

The similarity of this investigation, the reliability of scales ISN, ECO, WLQ were also ratified in studies by several authors ${ }^{(9,13-14)}$. They claim that these instruments meet the needs of researchers regarding the three parameters assessed - stress, Coping and presenteeism.

Demographic characterization data for this population are similar to those found in national ${ }^{(2,8,17)}$ and international investigations ${ }^{(18-21)}$. In relation to demographic and functional characteristics, a study of Portuguese health professionals demonstrated greater tendency to occupational stress in nurses, female, young, with less work experience and who perform work on rotating shifts ${ }^{(22)}$.

In this way, in the analysis of occupational stress, it was found that $66.7 \%$ of the population presented low stress. Similarly, a study conducted with 143 nurses from a university hospital showed that $55.25 \%$ of these professionals showed low level of stress and attributed this finding to the characteristics of the population studied, such as: doing post-graduation, do not keep other employment and use of the Resolutive Coping strategies ${ }^{(10)}$. In research with 360 hospital nurses from Taiwan, it was found that $26.06 \%$ presented low stress ${ }^{(23)}$.

Among the categories of the ISN, there was prevalence of stressors related to interpersonal relationships. In this sense, it is believed that labor relations involving the social support from colleagues, bosses and subordinates are fundamental determinants of worker's health. 
Researchers claim to be responsible for people, the example of the work in nursing, demand greater working time and attention devoted to the interaction, which increases the probability of occurrence of stress for interpersonal conflicts $^{(10)}$. Thus, it can be said that the development of more technical and less human relationships contributes to occupational stress. This type of relationship can be established in response to the pressures experienced in the daily work of nurses in units of assistance to critical and potentially critical patients.

In assessing the occupational Coping, the Control factor was signaled by $87.6 \%$ of nurses as the most widely used strategy. It shows that individuals make use of actions and proactive occupational environment cognitive revaluations. The confrontation is considered an intentional action, physical or mental, which begins in response to a situation that evaluates to estressor and is directed to external circumstances or internal states. Thus, it is possible to say that the problems in the workplace and its impact on health and well-being are recognized by the nurses in this study. Therefore, the possibility of actively face the problems identified is beneficial for the evaluation of stress and directed to the main causes of wear at work. These results are similar to another study ${ }^{(5)}$ and provide support to the assumption of the authors of $\mathrm{ECO}^{(13)}$ that the use of the control strategy is associated directly to favorable perception of the workplace and conversely to stress.

By this presenteeism analysis, evaluated by the loss of productivity, it was found an index up $4.84 \%$ to $75 \%$ of nurses. In this way, it is possible to consider that the percentage of lost productivity in this population has been reduced. The loss of productivity, even with low percentage, is indication that coexist, even if subtly, interference and consequences, whether for the service organization and institution, are for professionals and for the assistance provided.

In this study, the largest entry domain limitation for nurses was the physical demand (26.33\%). Thus, the ability to perform tasks requiring physical strength, endurance, movement, coordination and flexibility, was perceived as the most influential limitation for lost productivity of nurses in this study. This means that, in the last two weeks, these professionals have had restrictions on more than $25 \%$ of their time to perform tasks related to physical demands at work. From this result, it is displayed the repercussions of physical demands on the health of nurses as the peculiarities that involve customer service critical and potentially critical patients, including the requirements of mobilization of patients and equipment, transportation and the maneuvers are inherent in the assistance of unstable patients.

Between stress and presenteeism, the hypothesis of relationship was proven by direct and significant correlations between scores of these two scales. It is considered that the interrelationship between living and working conditions and individual characteristics can determine tolerance to work, being distinct for each worker. The degree of tolerance and how the worker adapt to work determines, in part, his health and ability to work $^{(24)}$. In this sense, studies ${ }^{(3,4,25)}$ pointed out that high demands at work, stress and the less control over activities are elements of presenteeism predictors and therefore accentuates the productivity loss.

In this study significant correlations between presenteeism and Coping factors were not identified. However, from the theoretical framework, it is possible to confirm the link between the use of a Resolutive Coping Strategy and a lower intensity of stress and, consequently, lower rates of lost productivity.

It is believed that to establish and implement interventions to reduce or mitigate the effects of presenteeism is necessary to broaden the perception beyond the cause of illness and consider situations that alter the condition of health and wellbeing of professionals ${ }^{(26)}$. This includes the constant evaluation of the occupational environment stressors and coping strategies used by workers, as well as the recognition of the relationship of these phenomenon with the specificities of the work demands of nurses.

\section{CONCLUSION}

In this study, $66.7 \%$ of nurses to critical and potentially critical patients presented low stress and $87.6 \%$ use the control as a strategy for Coping. There was a decrease of up to $4.84 \%$ in productivity. Added to this, there was statistically significant and direct correlation between the intensity of stress and the loss of productivity $(r=0.416 ; p<0.01)$ of nurses in the workplace.

Thus, it was observed that stress affects inversely on productivity of nurse, confirming the hypothesis partially of this research. On the relationship between Coping strategies and stress intensity, it has not been possible to identify statistically significant correlations, due to the prevalence of the control factor. However, considering the predominance of low stress and the use of the Control Strategy, it is possible that the use of such a strategy has minimized the stress of nurses, given that the use of this type of strategy is considered effective for minimizing the stress by the theoretical-conceptual reference.

It is noted that there are organizational or individual factors influence on productivity of the individual against the circumstances involving critical and potentially critical adult care. Special attention needs to be given to limitations of physical order, pointed out as responsible for the greatest loss of productivity and affect the health of nurses who have limitation in excess of $25 \%$ of their time to perform tasks related to physical demand, in addition to direct and significant correlation between stress scores and presenteeism. In this sense, the characteristics inherent
Stress, coping and presenteeism in nurses assisting critical and potentially critical patients Umann J, Guido LA, Silva RM 
in unstable patients assistance, insufficient resources and difficulties in interpersonal relationships are conditions that can cause damage to the physical and mental health of these professionals.

In a technical and technological reality in which labor relations occur in pressure/requirement for productivity and reducing costs, presenteeism is perceived as a negative condition to satisfactory economic performance in organizations. When it comes to health institutions, the product of the work involves promoting, the rehabilitation and recovery of health and well-being of individuals. Therefore, workers who work in this sector deserves special attention, because the benefit of the work of nursing to society in general is a result of their workforce (intellectual and physical).

It is essential to consider, from the research produced, with the knowledge of Coping strategies, it becomes possible to identify internal resources and/or externally available and improve the skills of the individual to a more effective engagement of situations, considering both the disease as their personal needs.

\section{REFERENCES}

1. Fernandes SMBA, Medeiros SM, Ribeiro LM. Estresse ocupacional e o mundo do trabalho atual: repercussões na vida cotidiana das enfermeiras. Rev Eletr Enferm [Internet]. 2008 [citado 2013 nov. 10];10(2):414-27. Disponível em: http:// www.fen.ufg.br/fen_revista/v10/n2/v10n2a13.htm

2. Schmidt DRC, Dantas RAS, Marziale MHP, Laus AM. Estresse ocupacional entre profissionais de enfermagem do bloco cirúrgico. Texto Contexto Enferm. 2009;18(2):330-7.

3. Martinez LF, Ferreira Al. Sick at work: presenteeism among nurses in a Portuguese public hospital. Stress Health. 2012;28(4):297-304.

4. Merrill RM, Aldana SG, Pope JE, Anderson DR, Coberley CR, Whitmer RW; Hero Research Study Subcommittee. Presenteeism according to healthy behaviors, physical health, and work environment. Popul Health Manag. 2012;15(5):293-301.

5. Ashker VE, Penprase B, Salman A. Work-related emotional stressors and Coping strategies that affect the well-being of nurses working in hemodialysis units. Nephrol Nurs J. 2012;39(3):231-6.

6. Umann J, Guido LA, Freitas EO. Produção de conhecimento sobre saúde e doença na equipe de enfermagem na assistência hospitalar. Ciênc Cuid Saúde. 2011;10(1):162-8.

7. Hamaideh SH. Occupational stress, social support, and quality of life among Jordanian mental health nurses. Issues Ment Health Nurs. 2012;33(1):15-23.

8. Jodas DA, Hadadd MCL. Burnout Syndrome among nursing staff from an emergency department of a university hospital. Acta Paul Enferm. 2009;22(2):192-7.
Thus, it is suggested the development of intervention strategies that seek to promote better working conditions in each labor context. It is believed that the combination of individual effort and organizational support can be an association in favor of good professional performance and a proper productivity work demands.

The type of institution in which the study was carried out can be considered a limiting factor for the assessment of presenteeism in these professionals, since in public hospitals link stability allows clearance for rehabilitation and recovery of health. This situation differs from private institutions, to impart other requirements in relation to productivity and assiduity.

Therefore, it should interpret and apply the results related to these phenomenon carefully. The stress is a dynamic phenomenon and the way individuals perceive their working environment can change over time. For this reason, the cross-sectional design used represents the current perception of these professionals outside the context lived in period of data collection.

9. Stacciarini JMR, Tróccoli BT. Instrumento para mensurar o estresse ocupacional: inventario de estresse em enfermeiros (IEE). Rev Latino Am Enfermagem. 2000;8(6):40-9.

10. Guido LA, Linch GFC, Pitthan LO, Umann J. Stress, coping and health conditions of hospital nurses. Rev Esc Enferm USP [Internet]. 2011 [cited 2013 Dec 05];45(6):1434-9. Available from: http://www.scielo.br/pdf/reeusp/v45n6/ en_v45n6a22.pdf

11. Laranjeira CA. O contexto organizacional e a experiência de stress: uma perspectiva integrativa. Rev Salud Pública. 2009;11(1):123-33.

12. Brasil. Ministério da Saúde; Agência Nacional de Vigilância Sanitária. Consulta Pública n. 21, de 27 de abril de 2006. Minuta de Resolução que define o regulamento técnico para funcionamento de serviços de atenção ao paciente crítico e potencialmente crítico [Internet]. Brasília; 2006 [citado 2009 out. 22]. Disponível em: http://www4.anvisa.gov.br/base/ visadoc/CP/CP\%5B14558-1-0\%5D.PDF

13. Pinheiro FA, Tróccoli BT, Tamayo MR. Mensuração de coping no ambiente ocupacional. Psicol Teor Pesqui. 2003;19(2):153-8.

14. Soárez PC, Kowalski CCG, Ferraz MB, Ciconelli RM. Tradução para português brasileiro e validação de um questionário de avaliação de produtividade. Rev Panam Salud Pública. 2007;22(1):21-8.

15. Field A. Descobrindo a estatística usando o SPSS. $2^{\text {a }}$ ed. Porto Alegre: Artmed; 2009. 
16. Brasil. Ministério da Saúde; Conselho Nacional de Saúde. Resolução n. 196, de 10 de outubro de 1996. Dispõe sobre diretrizes e normas regulamentadoras de pesquisas envolvendo seres humanos. Bioética. 1996;4(2 Supl):15-25.

17. Griep RH, Fonseca MJ, Melo ECP, Portela LF, Rotenberg L. Nurses of large public hospitals in Rio de Janeiro: socio demographic and work related characteristics. Rev Bras Enferm. 2013; 66 (n.esp):151-7.

18. Øyane NM, Pallesen S, Moen BE, Akerstedt T, Bjorvatn B. Associations between night work and anxiety, depression, insomnia, sleepiness and fatigue in a sample of Norwegian nurses. PLoS One. 2011;8(8): e70228.

19. Tarrant T, Sabo CE. Role conflict, role ambiguity, and job satisfaction in nurse executives. Nurs Admin Q. 2010;43(1):72-82.

20. Denis S, Shannon HS, Wessel J, Stratford P, Weller I. Association of low back pain, impairment, disability \& work limitations in nurses. J Occup Rehabil. 2007;17(2):213-26.

21. Wu H, Chi TS, Chen L, Wang L, Jin YP. Occupational stress among hospital nurses: cross-sectional survey. J Adv Nurs. 2010;66(3):627-34.
22. Silva MCM, Gomes ARS. Stress ocupacional em profissionais da saúde: um estudo com médicos e enfermeiros portugueses. Estudos Psicol (Natal). 2009;14(3):239-48.

23. Lee WL, Tsai SH, Tsai CW, Lee CY. A study on work stress, stress coping strategies and health promoting lifestyle among district hospital nurses in Taiwan. J Occup Health. 2011;53(5):377-83.

24. Milosevic M, Golubic R, Knezevic B, Golubic K, Bubas M, Mustajbegovic J. Work ability as a major determinant of clinical nurses' quality of life. J Clin Nurs. 2011;20(19-20):2931-8.

25. Jeon SH, Leem JH, Park SG, Heo YS, Lee BJ, Moon SH, et al. Association among working hours, occupational stress, and presenteeism among wage workers: results from the second korean working conditions survey. Ann Occup Environ Med. 2014;26(1):6-13

26. Coffeng JKI, Hendriksen IJ, Duijts SF, Twisk JW, van Mechelen W, Boot CR. Effectiveness of a combined social and physical environmental intervention on presenteeism, absenteeism, work performance, and work engagement in office employees. J Occup Environ Med. 2014;56(3):258-65. 